\title{
CES
}

COOPERATIVISMO E ECONOMÍA SOCIAL

Núm. 40 (2017-2018), páxs. 59-85

ISSN: 1130-2682

\section{AS COOPERATIVAS E OS REGIMES DO BENEFICIÁRIO EFETIVO}

\section{COOPERATIVES AND THE BENEFICIAL OWNER LEGAL REGIMES}

\author{
Maria Elisabete Ramos*
}

Recepción: 12/07/2018 - Aceptación: 17/10/2018

\footnotetext{
* Doutora em Direito pela Faculdade de Direito da Universidade de Coimbra. Professora Auxiliar da Faculdade de Economia da Universidade de Coimbra. Email: mgramos@ fe.uc.pt. Endereço postal: Faculdade de Economia da Universidade de Coimbra, Av. Dias da Silva, 165, 3004-512 Coimbra.
} 


\section{RESUMO}

A Lei 89/2017, de 21 de agosto, transpõe para a ordem jurídica nacional o Capítulo III da Diretiva (UE) 2015/849, do Parlamento Europeu e do Conselho, de 20 de maio de 2015, relativo às informações sobre o beneficiário efetivo. O Estado Português cumpriu estas obrigações internacionais relativas às "informações sobre o beneficiário efetivo", através da criação do registo interno do beneficiário efetivo e do registo central do beneficiário efetivo.

$\mathrm{O}$ artigo analisa e discute as novas obrigações declarativas a cargo da cooperativa e dos seus membros, previstas na Lei 89/2017, e as sanções previstas para o incumprimento de uma e outras.

Palavras-Chave: beneficiário efetivo, registos do beneficiário efetivo, «proprietário legal», cooperativas, incumprimento da lei e sanções.

\section{ABSTRACT}

The Portuguese Law n. ${ }^{\circ} 89 / 2017,21^{\text {st }}$ august transposes into the Portuguese legal system the Chapter III of the Directive (EU) 2015/849 of the European Parliament and of the Council of 20 may 2015, regarding the beneficial ownership information. The Portuguese State complies with its international obligations regarding the «beneficial ownership information» by the legal provisions on the corporate register of beneficial ownership and on the central register of the beneficial ownership.

This paper highlights the new reporting obligations which are imposed to the legal owner, set forth by the Law n. ${ }^{\circ} 89 / 2017$, and debates the sanctions for the noncompliance of such obligations.

KEY WORDS: beneficial ownership, beneficial ownership registers, «legal owner», cooperatives, breach of the law and sanctions. 
SUMÁRIO: 1. COOPERATIVAS E PREVENÇÃO DE BRANQUEAMENTO DE CAPITAIS. 1.1. A Diretiva (UE) 2015/849 do Parlamento Europeu e do Conselho. 1.2. Reações legais ao branqueamento de capitais através de "corporate vehicles". 2. LEI 89/2017 E AS REGRAS QUE NÃO ALTERADAS. 2.1. Identificação do cooperador e de membro investidor no ato de constituição da cooperativa. 2.2. Regras relativas ao cumprimento da obrigação de entrada em dinheiro e de outras contribuições que não integram o capital social. 3. SÍNTESE DAS ALTERAÇÕES LEGISLATIVAS INTRODUZIDAS PELA LEI 89/2017. 4. DUALIDADE DE REGISTOS DO BENEFICIÁRIO EFETIVO - O REGISTO INTERNO DE BENEFICIÁRIO EFETIVO. 4.1. Critérios para a determinação do beneficiário efetivo. 4.2. Criação e organização do registo interno do beneficiário efetivo. 4.3. As novas obrigações declarativas de membros da cooperativa. 5. RESPONSABILIDADE CIVIL POR DECLARAÇÕES INEXACTAS OU DEFICIENTES. 6. DO CUMPRIMENTO DA OBRIGAÇÃO DE ATUALIZAÇÃO PERMANENTE DO REGISTO INTERNO DE BENEFICIÁRIO EFETIVO. 7. DO REGISTO CENTRAL DO BENEFICIÁRIO EFETIVO - PUBLICIDADE E RESTRIÇÃO DE DIREITOS FUNDAMENTAIS. 8. DO INCUMPRIMENTO INJUSTIFICADO DA OBRIGAÇÃO DE INFORMAÇÃO A CARGO DO MEMBRO DA COOPERATIVA - ALGUMAS INTERROGAÇÕES JURÍDICAS. 9. SANÇÕES APLICÁVEIS À COOPERATIVA. 10. A DIRETIVA (UE) 2018/843 DO PARLAMENTO EUROPEU E DO CONSELHO, DE 30 DE MAIO DE 2018. 11. QUESTÕES RELATIVAS À ENTRADA EM VIGOR DA LEI 89/2017. 12. CONCLUSÃO. 13. BIBLIOGRAFIA E OUTRAS FONTES.

CONTENTS: 1. COOPERATIVES AND THE PREVENTION OF THE MONEY LAUNDERING. 1.1. Directive (EU) 2015/849 of the European Parliament and of the Council of 20 May 2015. 1.2. Legal reactions to the money laundering through corporate vehicles. 2. LAW 89/2017 AND THE UNCHANGED RULES. 2.1. Nomination of the cooperative member at the cooperative incorporation act. 2.2. Rules on the cooperative member's contributions. 3. MAIN REFORMS INTRODUCED BY THE LAW 89/2017. 4. TWO BENEFICIAL OWNER REGISTERS - THE INTERNAL BENEFICIAL OWNER REGISTER. 4.1. Criteria to determine the beneficial owner. 4.2. Creation and management of the internal beneficial owner register. 4.3. The cooperative members' communication obligations. 5. LIABILITY ARISING FROM INCORRECT INFORMATION. 6. COMPLIANCE WITH THE OBLIGATION TO UPDATE THE INTERNAL BENEFICIAL OWNER REGISTER. 7. BENEFICIAL OWNER CENTRAL REGISTER - PUBLICITY AND FUNDAMENTAL RIGHTS RESTRICTIONS. 8. UNJUSTIFIED BREACH OF THE COOPERATIVE MEMBERS' OBLIGATIONS - SOME LEGAL ISSUES. 9. SANCTIONS APPLICABLE TO THE COOPERATIVE. 10. DIRECTIVE (EU) 2018/843 OF THE EUROPEAN PARLIAMENT AND OF THE COUNCIL OF 30 MAY 2018. 11. SOME LEGAL ISSUES RELATED TO THE LAW 89/2017 ENTERING INTO FORCE. 12. CONCLUSION. 13. BIBLIOGRAPHY AND OTHER RESOURCES. 


\section{CoOperativas E PREVEnÇão DE BRANQUEAMENTO DE CAPITAIS}

\subsection{A Diretiva (UE) $2015 / 849$ do Parlamento Europeu e do Conselho}

Diretiva (UE) 2015/849, do Parlamento Europeu e do Conselho, de 20 de
maio de $2015^{1}$, conhecida internacionalmente como $4^{\text {th }}$ AMLD, pretende
que os Estados-Membros alcancem os seguintes resultados': $a$ ) assegurar que o branqueamento de capitais e o financiamento do terrorismo são proibidos; b) exigir que as instituições de crédito, as instituições financeiras e determinados profissionais adotem medidas de due diligence na sua relação com os clientes ou quando participam em transações de certo valor; $c$ ) garantir que estas pessoas e entidades reportam a entidades competentes o conhecimento ou as suspeitas de que estão a ter lugar atividades de lavagem de dinheiro ou de financiamento de terrorismo; e) exigir que estas pessoas mantenham registos e informações relativas à sua clientela e ao estabelecimento de relações comerciais; $f$ ) impor que estas pessoas adotem políticas e procedimentos apropriados, para cumprir as imposições da Diretiva e a previsão sanções apropriadas para o incumprimento de tais obrigações ${ }^{3}$.

\footnotetext{
1 Trata-se da Diretiva relativa à prevenção da utilização do sistema financeiro para efeitos de branqueamento de capitais ou de financiamento do terrorismo, que altera o Regulamento (UE) n ${ }^{\circ}$ 648/2012 do Parlamento Europeu e do Conselho, e que revoga a Diretiva 2005/60/CE do Parlamento Europeu e do Conselho e a Diretiva 2006/70/CE da Comissão. A Diretiva (UE) 2018/843 do Parlamento Europeu e do Conselho de 30 de maio de 2018 altera a Diretiva (UE) 2015/849 relativa à prevenção da utilização do sistema financeiro para efeitos de branqueamento de capitais ou de financiamento do terrorismo. Esta última diretiva tem por "objetivo abranger todas as utilizações potenciais das moedas virtuais" (considerando 10).
}

2 Sobre as anteriores três diretivas dedicadas ao branqueamento de capitais, v. George Walker, Robert Purves, Michael Blair, Finantial Services Law, 4th edition, 2018, 14.41 e ss.

3 Um dos aspetos que ganha cada vez mais expressão é a questão relativa às criptomoedas e ao crime de lavagem de dinheiro. Kay Firth-Butterfield, Richard Brent, Tom Grant, Part. VIII Future of the International Law of Tainted Money, 24 Virtual Currencies, Artificial Intelligence, and Emerging Legal Questions", Banks and Financial Crime: The international law of tainted Money, $2^{\text {nd }}$ edition, Oxford Legal Research Library, 2017, pág.9, identificam que o principal risco suscitado pelas criptomoedas, do ponto de vista do combate ao branqueamento de capitais, é que "Virtual currency enables a user to avoid contact with the institution on which modern anti-money laundering law heretofore has relied". Uma das formas de regular a criptomoeda é sujeitá-la aos instrumentos de supervisão da Diretiva que previne o branqueamento de capitais. Com muito interesse sobre o funcionamento da tecnologia blockchain, criptomoedas e branqueamento de capitais, v. Philipp Paech, "The governance of blockchain financial networks", Modern Law Review, 80, 6 (2017), pág.1073, ss, que sublinha o anonimato propiciado pela tecnologia blockchain, e por outro lado, a inexistência ou desnecessidade de intermediários nas operações feitas através das redes blockchains. Justamente, tendo em conta os riscos suscitados por esta tecnologia, está a ser preparada uma Diretiva que venha sujeitar a regulação as chamadas "moedas virtuais". É interessante, neste contexto, o Parecer do Banco Central Europeu, Opinion of the European Central Bank of 12 October 2016 on a proposal for a directive of the European Parliament and of the Council amending Directive (EU) 2015/849 on the prevention of the 
Reconhece esta Diretiva que o "branqueamento de capitais e o financiamento do terrorismo ocorrem com frequência num contexto internacional" e que a "ação da União deverá continuar a ter particularmente em conta as Recomendações do $\mathrm{GAFI}^{4}$ e os instrumentos de outros organismos internacionais de luta contra o branqueamento de capitais e o financiamento do terrorismo ${ }^{5}$. A fim de reforçar a eficácia da luta contra o branqueamento de capitais e o financiamento do terrorismo, os atos legislativos pertinentes da União deverão, quando adequado, ser alinhados com os Padrões Internacionais de Combate ao Branqueamento de Capitais e ao Financiamento do Terrorismo e da Proliferação adotados em fevereiro de 2012 pelo GAFI (as «Recomendações revistas do GAFI»"6. (Considerando 4).

Uma das recomendações do GAFI alerta os países para a necessidade de serem adotadas medidas destinadas a "impedir a utilização abusiva das pessoas coletivas para fins de branqueamento de capitais ou de financiamento do terrorismo." Acrescenta, ainda, o GAFI que "os países deveriam assegurar que existe informação adequada, exata e atualizada sobre os beneficiários efetivos e sobre o controlo das pessoas coletivas, suscetível de ser obtida ou consultada em tempo útil, pelas autoridades competentes"?.

use of the financial system for the purposes of money laundering or terrorist financing and amending Directive 2009/101/EC (CON/2016/49), que, entre outros aspetos, salienta que "virtual currencies' do not qualify as currencies from a Union perspective". O Banco Central Europeu propõe que a definição de moeda virtual deve ser revista: "More recent digital currencies, which are based on more sophisticated distributed ledger and block chain technology, have a large array of uses that go beyond payment purposes, including for example, online casinos. In the light of that above, the ECB suggests that the proposed directive also refers to other possible uses of virtual currencies in the proposed definition of that term". Na doutrina portuguesa, v. Mendes Correia, F., «A tecnologia descentralizada de registo de dados (Blockchain)», O novo Direito dos Valores Mobiliários. I Congresso sobre Valores Mobiliários e Mercados Financeiros, coord. de Paulo Câmara, Almedina, Coimbra, 2017, pág. 447, ss. No dominio dos seguros, v. Alarcón Fidalgo, Joaquín, «La aportación del uso masivo de datos (big data) y de la cadena de bloques (blockchain) a la cadena de valor del seguro», RES, 173 (2018), pág. 63, ss.

4 Acrónimo para Grupo de Ação Financeira (em inglês, Financial Action Task) que é um organismo intergovernamental instituído em 1989.

5 Em novembro de 2017, o sistema português de prevenção e combate ao branqueamento de capitais e ao financiamento do terrorismo e da proliferação de armas de destruição em massa foi avaliado com nota máxima no plenário do Grupo de Ação Financeira - GAFI/FATF. O relatório está disponível em http://www.fatf-gafi.org/publications/mutualevaluations/documents/mer-portugal-2017.html (acesso em 7 de maio de 2018). O relatório é claro em sublinhar que «Progress still needs to be made regarding the understanding of the beneficial ownership (BO) requirements».

6 Veja-se as Recomendações, elaboradas em 2012, pelo Grupo de Ação Financeira intituladas na versão original «International Standards on Combating Money Laundering and the Financing of Terrorism.

\& Proliferation» (disponíveis em <www. http://www.fatf-gafi.org/publications/fatfrecommendations/ documents/fatf-recommendations.html $>$. Consultadas em 8 de julho de 2018).

7 Trata-se da Recomendação 24, inserida no capítulo relativo à «transparência e beneficiários efetivos de pessoas coletivas e entidades sem personalidade jurídica (legal arrangements)». As Recomendações do GAFI estão disponíveis em <http://www.fatf-gafi.org>. 
Para quem quer praticar crimes ou atividades ilícitas, o anonimato proporcionado por determinadas pessoas coletivas é uma vantagem. Justamente, a virtuosa separação subjetiva (pessoa coletiva/membros) e o anonimato dos membros são suscetíveis de serem degradados em instrumentos de ocultação de identidade de autores de crimes e, tornarem-se peças de atividades criminosas $8 / 9$.

O branqueamento de capitais surge definido no art. $1^{\circ}$, n. ${ }^{\circ} 3$, da Diretiva (UE) 2015/849 do Parlamento Europeu e do Conselho de 20 de maio de 2015, mas de modo abreviado e sintético podemos caraterizar este crime como o processo mediante o qual o dinheiro proveniente de atividades ilícitas sofre transformações várias no fim das quais aparenta ter sido gerado por atividades lícitas ${ }^{10}$. Neste circuito de branqueamento de capitais, as pessoas que obtêm dinheiro através de fontes ilícitas precisam de construir uma aparência de licitude na obtenção de tais rendimentos. Para tanto, entre outros expedientes, são introduzidos neste circuito de branqueamento de capitais "corporate vehicles" que, através de expedientes vários, contribuem para ofuscar a origem ilícita do dinheiro e dar-lhe uma «capa» de licitude.

É tradicional (e antiga) a afirmação (usada em diversos contextos) que o «sol é o melhor desinfetante». Quer-se, por intermédio dela, valorizar a transparência, a clareza e os benefícios que ela comporta. O Grupo de Ação Financeira (GAFI) elege a transparência como um dos mecanismos idóneos a prevenir que as sociedades sejam degradadas em instrumentos de branqueamento de capitais, dedicando a Secção E das suas recomendações de 2012 ao tema da «transparência e beneficiários efetivos de pessoas coletivas e entidades sem personalidade jurídica (legal arrangements)». Em matéria de transparência e beneficiários efetivos, o GAFI recomenda «que os países deveriam adotar medidas para impedir a utilização abusiva das pessoas coletivas para fins de branqueamento de capitais ou de financiamento do terrorismo. Os países deveriam assegurar que existe informação adequada, exata e atualizada sobre os beneficiários efetivos e sobre o controlo das

\footnotetext{
8 O sigilo profissional é considerado nas nossas sociedades como um instrumento virtuoso a que vários profissionais estão deontologicamente vinculados. Pense-se, por exemplo, no caso dos advogados. O que acontece é que, a coberto de tal sigilo, e desvirtuando-o para fins ilícitos, pode a reserva e segredo por ele garantidos serem usados para fins ilícitos ou criminosos. A Diretiva (UE) 2015/849 do Parlamento Europeu e do Conselho impõe aos Estados-Membros que a «consultoria jurídica deverá continuar a estar sujeita à obrigação de segredo profissional, salvo se o membro de profissão jurídica independente participar em atividades de branqueamento de capitais ou de financiamento do terrorismo, se prestar consulta jurídica para efeitos de branqueamento de capitais ou de financiamento do terrorismo ou se o membro de profissão jurídica independente estiver ciente de que o cliente solicita os seus serviços para esses efeitos».

9 OECD, Behind the corporate veil. Using corporate entities for illicit purposes, 2001, pág.1, s.

${ }^{10}$ Para a definição de branqueamento de capitais no ordenamento jurídico português, v. também o art. $2^{\circ}, 1, j$ ), da Lei n. ${ }^{\circ} 83 / 2017$, de 18 de agosto.
} 
pessoas coletivas, suscetível de ser consultada, em tempo útil, pelas autoridades competentes».

Acolhendo as recomendações do GAFI, a Diretiva 2015/849 é perentória em afirmar que é «necessário identificar todas as pessoas singulares que detêm a propriedade ou o controlo de uma pessoa coletiva» (Considerando 12). A identificação não só do «proprietário legal» como de beneficiário(s) efetivo(s) de participações sociais é uma das medidas de transparência destinadas a prevenir a utilização de sociedades para atividades ilícitas de branqueamento de capitais (Considerando 12 da Diretiva (UE) 2015/849). O Considerando (14) da Diretiva é claro ao eleger a «necessidade de dispor de informações exatas e atualizadas sobre o beneficiário efetivo como o fator essencial para rastrear os agentes do crime, que de outro modo poderão dissimular a sua identidade numa estrutura societária ${ }^{11}$.

Para cumprir este resultado, a Diretiva exige que os Estados-Membros assegurem que as entidades (e não só entidades societárias) constituídas nos seus territórios «obtêm e conservam informações suficientes, exatas e atuais sobre os seus beneficiários efetivos, além das informações básicas como a denominação social e o endereço, a prova de constituição e a estrutura de propriedade» (Considerando (14) da Diretiva). Por outro lado, os Estados-Membros «devem assegurar o armazenamento das informações sobre o beneficiário efetivo num registo central situado fora da sociedade» ${ }^{12}$ (Considerando (14) da Diretiva).

\subsection{Reações legais ao branqueamento de capitais através de "corporate vehicles"}

A ordem jurídica portuguesa tipifica o crime de branqueamento no art. $368^{\circ}-\mathrm{A}$ do Código Penal ${ }^{13}$, enquanto crime contra a realização da justiça. Crime que, nos termos da legislação vigente, pode ser praticado por pessoas coletivas.

Como manifestação da superação do dogma "societas delinquire non potest" 14 , o art. $11^{\circ}, 2$, do Código Penal, determina que "as pessoas coletivas e entidades

\footnotetext{
${ }^{11}$ O beneficiário efetivo é "a pessoa ou pessoas singulares que, em última instância, detêm a propriedade ou controlo do cliente e ou a pessoa ou pessoas singulares por conta de quem é realizada uma operação ou atividade (art. $2^{\circ}$, n. $^{\circ} 1$, h), da Lei n. ${ }^{\circ} 83 / 2017$, de 18 de agosto). Sobre a titularidade por conta de participações sociais", v. José Engrácia Antunes, "A titularidade por conta de participações sociais - breve apontamento", DSR, 10, 19(2018), 51, ss.

${ }^{12} \mathrm{O}$ itálico não consta do texto original.

${ }^{13}$ Alterado pelo art. $186^{\circ}$ da Lei 83/2017, de 18 de agosto. Este diploma estabelece medidas de combate ao branqueamento de capitais e ao financiamento do terrorismo, transpõe parcialmente as Diretivas 2015/849/UE, do Parlamento Europeu e do Conselho, de 20 de maio de 2015, e 2016/2258/UE, do Conselho, de 6 de dezembro de 2016, altera o Código Penal e o Código da Propriedade Industrial e revoga a Lei n. ${ }^{\circ}$ 25/2008, de 5 de junho, e o Decreto-Lei n. ${ }^{\circ}$ 125/2008, de 21 de julho.

${ }^{14}$ V. com muito interesse Faria Costa, J., «Responsabilidade jurídico-penal da empresa e dos seus órgãos (ou a reflexão sobre a alteridade nas pessoas colectivas à luz do direito penal)», in: Direito
} 
equiparadas, com exceção do Estado, de pessoas coletivas no exercício de prerrogativas de poder público e de organizações de direito internacional público, são responsáveis pelos crimes previstos (...) no[s] artigo[s] 368. ${ }^{\circ}-\mathrm{A}(\ldots)$ quando cometido[s]: a) Em seu nome e no interesse coletivo por pessoas que nelas ocupem uma posição de liderança; ou b) Por quem aja sob a autoridade das pessoas referidas na alínea anterior em virtude de uma violação dos deveres de vigilância ou controlo que lhes incumbem"15. A este crime o Código Penal reage com a pena de dissolução decretada pelo tribunal quando "a pessoa coletiva ou entidade equiparada tiver sido criada com a intenção exclusiva ou predominante de praticar os crimes indicados no n. ${ }^{\circ} 2$ do artigo $11 .^{\circ}$ ou quando a prática reiterada de tais crimes mostre que a pessoa coletiva ou entidade equiparada está a ser utilizada, exclusiva ou predominantemente, para esse efeito, por quem nela ocupe uma posição de liderança" (art. 90-F do Código Penal). Nos restantes casos, aplicar-se a pena de multa, nos termos do art. $90^{\circ}$-B, do Código Penal.

Embora muito relevante, a reação jurídico-penal não é a única reação contra o branqueamento de capitais, através de pessoas coletivas, designadamente cooperativas. Na ordem jurídica portuguesa, nos termos do art. $141^{\circ}, 1, d$ ), do CSC, a ilicitude superveniente do objeto contratual (designadamente porque a sociedade se degrada em instrumento de branqueamento de capitais) constitui uma das causas de "dissolução imediata" da sociedade ${ }^{16}$. Segundo o art. $141^{\circ}, 2$, do CSC, os sócios podem deliberar, por maioria simples dos votos, produzidos na assembleia, o reconhecimento da dissolução e, bem assim, pode qualquer sócio, sucessor de sócio, credor da sociedade ou credor de sócio de responsabilidade ilimitada promover a justificação notarial ou o procedimento simplificado de justificação ${ }^{17}$.

À luz do art. $\left.112^{\circ}, 1, h\right)$, Código Cooperativo de 2015 (CCoop) $^{18}$, constitui causa de dissolução a «decisão judicial transitada em julgado que verifique que a cooperativa não respeita no seu funcionamento os princípios cooperativos, que

penal económico e europeu: textos doutrinários, vol., I. Problemas gerais, Coimbra Editora, Coimbra, 1998, pág. 501, ss; Aires de Sousa, S., «Societas publicas (non) delinquere potest: reflexões sobre a irresponsabilidade dos entes públicos no ordenamento jurídico português», Actas do XV Encuentro AECA Nuevos caminos para Europa: El papel de las empresas y los gobiernos, 20-21 de setembro de 2012, Obra digital, disponível em <http://www.aeca.es/xvencuentroaeca/cd/7f.pdf>.

15 V. Ramos, Maria Elisabete, O seguro de responsabilidade civil dos administradores. Entre a exposição ao risco e a delimitação da cobertura, Almedina, Coimbra, 2010, pág. 64, ss; Aires de Sousa, S., «A responsabilidade criminal do dirigente: algumas considerações acerca da autoria e comparticipação no contexto empresarial», Estudos em Homenagem ao Prof. Doutor Jorge de Figueiredo Dias, Boletim da Faculdade de Direito, Stvdia Ivridica 98, Vol. II, 2009/2010, Coimbra, pág.1005, ss.

16 V. Costa, Ricardo, «Artigo $141^{\circ} »$, Código das Sociedades Comerciais em comentário, coord. de J. M. Coutinho de Abreu, vol. II, $2^{a}$ ed., Almedina, Coimbra, 2015, pág. 630, ss.

17 V. Costa, Ricardo, «Artigo $142^{\circ} »$, Código das Sociedades Comerciais em comentário, coord. de J. M. Coutinho de Abreu, vol. II, $2^{a}$ ed., Almedina, Coimbra, 2015, pág. 647, ss.

${ }_{18}$ Aprovado pela Lei n. ${ }^{\circ}$ 119/2015, de 31 de agosto, e alterado pela Lei n. ${ }^{\circ}$ 66/2017, de 9 de agosto. 
utiliza sistematicamente meios ilícitos para a prossecução do seu objeto ou que recorre à forma de cooperativa para alcançar indevidamente benefícios legais» ${ }^{19}$. Assim, na eventualidade de uma determinada cooperativa se degradar em instrumento de branqueamento de capitais e essa prática ilícita for reconhecida por sentença transitado em julgado, a referida cooperativa é objeto de dissolução e, posteriormente, liquidado e partilhado o seu património (arts. $113^{\circ}$ e $114^{\circ}$ do CCoop. $)^{20}$.

Estas reações destinadas a punir a utilização de pessoas coletivas como peças da engrenagem de branqueamento de capitais não são suficientes para a eficaz prevenção de tais atividades ilícitas. Para lá destas, há que dotar a ordem jurídica de medidas preventivas (e de outras medidas repressivas) de combate ao branqueamento de capitais e ao financiamento do terrorismo. É este o caminho seguido pela Diretiva (UE) 2015/849 do Parlamento Europeu e do Conselho, de 20 de maio de 2015 que, em Portugal, foi transposta pela Lei n. ${ }^{\circ}$ 83/2017, de 18 de agosto, e mais tarde, pela Lei 89/2017, de 21 de agosto.

Entre muitas outras medidas de transparência, a Lei 83/2017, de 18 de agosto, o art. $34^{\circ}, 1$, antecipa que "as informações sobre os beneficiários efetivos são registadas no registo central do beneficiário efetivo, o qual é regulado por legislação específica". Transpondo o Capítulo III da Diretiva (UE) 2015/849, e dando cumprimento ao art. $34^{\circ}$ da Lei n. ${ }^{\circ} 83 / 2017$, de 18 de agosto, a Lei 89/017 ${ }^{21}$ aprova o Regime Jurídico do Registo Central do Beneficiário Efetivo ${ }^{22}$.

$\mathrm{O}$ presente artigo pretende estudar os impactos que os regimes jurídicos do beneficiário efetivo poderão ter quer para a cooperativa e para os membros da cooperativa (ou seja, cooperadores e membros investidores).

Para cumprir este objetivo, o artigo:

a) Identifica e analisa as principais alterações introduzidas pela Lei 89/2017, de 21 de agosto;

\footnotetext{
${ }^{19}$ Sobre esta causa de dissolução das cooperativas e a sua justificação, v. Cunha, C., «Artigo $112^{\circ}$ », Código Coopeativo anotado, coord. de Deolinda Meira, Maria Elisabete Ramos, Almedina, Coimbra, 2018, ponto 1.1. (no prelo).

${ }^{20}$ Sobre o processo de liquidação e partilha de património, v. Cunha, C., «Artigo 113», Código Coopeativo anotado, coord. de Deolinda Aparício Meira, Maria Elisabete Ramos, Almedina, Coimbra, 2018 (no prelo). Sobre as particularidades do destino do património cooperativo em liquidação, v. Meira, Deolinda, «Artigo $114^{\circ}$ », Código Coopeativo anotado, coord. de Deolinda Meira, Maria Elisabete Ramos, Almedina, Coimbra, 2018 (no prelo). Nos termos do art. $4^{\circ}, e$ ), do CCoop. , a dissolução e o encerramento da liquidação estão sujeitos a registo comercial. Trata-se de registo obrigatório comercial obrigatório, nos termos do art. $15^{\circ}, \mathrm{n}^{\circ} 1$, do CRCom.

${ }^{21}$ Para o conhecimento das medidas de transposição adotadas por outros Estados-Membros, v. <https:// eur-lex.europa.eu/legal-content/PT/NIM/?uri=celex:32015L0849>.

${ }^{22}$ Sobre os benefícios privados do controlo, v. Cancela de Abreu, Miguel, «Private benefits of controlo - Do aproveitamento pessoal do controlo societário», DSR, 8, 15 (2015), pág.151, ss.
} 
b) Carateriza o registo interno do beneficiário efetivo e o registo central de beneficiário efetivo e sublinha as diferentes funções, naturezas e regras que os distinguem;

c) Elenca as novas obrigações declarativas a cargo do membro da cooperativa perante esta e evidencia o dever de o órgão de administração e de representação dotar a cooperativa de um registo interno do beneficiário efetivo cuja organização a Lei n. ${ }^{o}$ 89/2017 não regula;

d) Autonomiza as obrigações declarativas da cooperativa perante o Registo Central do Beneficiário Efetivo;

e) Questiona as sanções aplicáveis ao membro da cooperativa incumpridor da sua obrigação de informação perante a sociedade;

f) Evidencia as severas sanções aplicáveis à cooperativa que não cumpra as suas obrigações perante o registo central do beneficiário efetivo;

g) Discute a constitucionalidade de alguns dos aspetos de regime do registo central do beneficiário efetivo, tendo em conta tutela constitucional da proteção de dados pessoais e a proteção da iniciativa cooperativa.

\section{LEI 89/2017 E AS REGRAS QUE NÃO SÃO ALTERADAS}

\subsection{Identificação do cooperador e de membro investidor no ato de constituição da cooperativa}

A Lei 89/2017, de 21 de agosto, que aprova o Regime do Registo Central do Beneficiário efetivo, não introduziu alterações nos requisitos relativos à identificação dos membros da cooperativa no ato constituinte. Assim, nos termos do art. $\left.13^{\circ}, 1, h\right)$, do CCoop. , a ata da assembleia de fundadores deve identificar os fundadores que tiverem aprovado a ata e, por força do art. $13^{\circ}, 1, i$ ), do CCoop. , deve incluir a identificação dos membros investidores quando os houver. Ora o ato constituinte da sociedade é obrigatoriamente inscrito no registo comercial, nos termos dos arts. $\left.4^{\circ}, a\right), 15^{\circ}, 1$, do CRCom. Por força do art. $\left.70^{\circ}, 1, b\right)$, do CRCom., é obrigatória a publicação do ato de registo de constituição da cooperativa.

A Lei 89/2017, de 21 de agosto, deixa intocadas as regras relativas ao registo e publicidade dos atos de constituição da cooperativa e identificação de cooperadores e membros investidores.

\subsection{Regras relativas ao cumprimento da obrigação de entrada em dinheiro e de outras contribuições que não integram o capital social}

Recorde-se que o propósito último da Diretiva (UE) 2015/849 é «prevenir a utilização do sistema financeiro para efeitos de branqueamento de capitais e de 
financiamento do terrorismo». A Diretiva reconhece que «a realização de pagamentos de elevados montantes em numerário é altamente vulnerável ao branqueamento de capitais e ao financiamento do terrorismo» (Considerando (6)).

$\mathrm{O}$ que nos conduz às regras relativas ao cumprimento da obrigação de entrada em dinheiro nas cooperativas (art. $84^{\circ}, 1$, do CCoop. ) e de outras contribuições (em dinheiro) que não integram o capital social (como sejam as joias de admissão ou a emissão de títulos de investimento ou de obrigações, nos termos do art. $90^{\circ}$ ). Efetivamente, importa apurar se estas regras

Embora o CCoop. não o diga expressamente, parece que, por força do art. $9^{\circ}$ do CCoop. e do art. $277^{\circ}, 3$, do CSC., o montante das entradas em dinheiro deve ser depositado em conta bancária aberta em nome da cooperativa. Quanto às restantes contribuições em dinheiro que não integram o capital social (art. 90 do CCoop. ), o Código Cooperativo nada diz sobre a obrigatoriedade de serem depositadas em conta bancária da cooperativa.

\section{Síntese DAS ALteraÇÕES LEGISLATIVAS INTRODUZIDAS PELA LEI 89/2017}

$\mathrm{O}$ quadro jurídico-cooperativo português existente à data da entrada em vigor da Lei 89/2017, de 21 de agosto, não é suficiente para cumprir as exigências da Diretiva 2015/849 (em particular, o Capítulo III) pois aquele versa a «propriedade legal» da participação social e não o beneficiário efetivo.

A Diretiva exige que os Estados-Membros assegurem que as sociedades constituídas nos seus territórios «obtêm e conservam informações suficientes, exatas e atuais sobre os seus beneficiários efetivos (...) e a estrutura de propriedade» (Considerando (14). Por outro lado, os Estados-Membros «devem assegurar o armazenamento das informações sobre o beneficiário efetivo num registo central situado fora da sociedade» (Considerando (14)).

Estas exigências da União Europeia em matéria de transparência quer quanto à «estrutura da propriedade» da entidade quer quanto ao «beneficiário efetivo» (Considerando (14)) são concretizadas no Capítulo III da Diretiva (UE) 2015/849, intitulado «informações sobre os beneficiários efetivos».

A abrir este III Capítulo, o art. 30º 1 da Diretiva (UE) 2015/849 determina que «Os Estados-Membros asseguram que as entidades societárias e outras pessoas coletivas constituídas no seu território são obrigadas a obter e conservar informações suficientes, exatas e atuais sobre os seus beneficiários efetivos, incluindo dados detalhados sobre os interesses económicos detidos». Além disso, impõe o mesmo art. $30^{\circ}, 1,2^{\circ}$ parágrafo que «Os Estados-Membros asseguram que essas entidades são obrigadas a apresentar às entidades obrigadas, além das informações sobre o proprietário legal, informações sobre o beneficiário efetivo, 
quando as entidades obrigadas tomarem medidas de diligência quanto à clientela nos termos do Capítulo II».

Na ordem jurídica nacional, a Lei 89/2017, de 21 de agosto, transpõe o Capítulo III da Diretiva (UE) 2015/849, do Parlamento Europeu e do Conselho, de 20 de maio. Fá-lo pela aprovação do Regime Jurídico do Registo Central do Beneficiário Efetivo (RRCBE) e, além disso, no que tange as cooperativas, pelas seguintes inovações legislativas: $a$ ) identificação dos beneficiários efetivos das participações sociais nos documentos que formalizem a constituição de cooperativa (arts. $3^{\circ}$, e $7^{\circ}$ da Lei 89/2017, e art. $3^{\circ}$ do $\mathrm{RRCBE}$ ); $b$ ) registo interno do beneficiário efetivo (arts. $4^{\circ}$ e $7^{\circ}$ da Lei 89/2017, e art. $3^{\circ}$ do RRCBE); c) obrigação de informação a cargo do membro da cooperativa e consequências jurídicas do incumprimento injustificado ( $\operatorname{arts.} 5^{\circ}$ e $7^{\circ}$ da Lei 89/2017, e art. $3^{\circ}$ do RRCBE); $d$ ) previsão de sanções que reagem ao incumprimento pela cooperativa das obrigações declarativas (arts. $6^{\circ}$ e $7^{\circ}$ da Lei 89/2017, e arts. $3^{\circ}$ e $34^{\circ}$ do RRCBE), e) alterações legislativas em vários diplomas legais.

\section{DuAlidADE DE REGISTOS DO BENEFICIÁRIO EFETIVO - O REGISTO INTERNO DE BENEFICIÁRIO EFETIVO}

\subsection{Critérios para a determinação do beneficiário efetivo}

Membros da cooperativa são, nos termos dos arts. $19^{\circ}$ e $20^{\circ}$ do CCoop. , os cooperadores e os membros investidores. Tanto uns como outros podem ser pessoas singulares ou pessoas coletivas. Os membros da cooperativa são, usando as expressões da Diretiva (EU) 2015/849, os «proprietários legais».

Quem são os beneficiários efetivos dos interesses económicos detidos por cooperadores ou por membros investidores? A esta pergunta o Código Cooperativo não responde. A definição de beneficiário efetivo é oferecida no art. $3^{\circ}, 6$, da Diretiva (UE) 2015/849 que o carateriza como «a pessoa ou pessoas singulares que, em última instância, detêm a propriedade ou o controlo do cliente e/ou a pessoa ou pessoas singulares por conta de quem é realizada uma operação ou atividade». Segue-se a aplicação/concretização deste critério genérico em caso das «entidades societárias» $\left(\operatorname{art} .3^{\circ}, 6, a\right)$ ), dos «fundos fiduciários (trusts)» (art. 3o, 6, b)) e de «pessoas coletivas como fundações e centros de interesses coletivos sem personalidade jurídica similares a fundos fiduciários» $\left(\right.$ art. $\left.3^{\circ}, 6, c\right)$ ). Expressamente, a Diretiva não oferece a concretização do referido critério genérico para o caso das cooperativas. Também o art. $30^{\circ}$ da Lei 83/2017 não apresenta um critério específico de identificação do beneficiário efetivo para as entidades de natureza cooperativa.

Na ordem jurídica portuguesa mantém-se a discussão em torno da questão de saber se as cooperativas são ou não sociedades. No entanto, a opinião dominante 
considera que as cooperativas não são sociedades ${ }^{23}$. Por consequência, a questão que se levanta é a de saber se o critério de determinação do beneficiário efetivo, o caso das cooperativas, é o que se aplica às entidades societárias (art. 30, 1, da Lei 83/2017) ou é outro o critério aplicável.

Parece-me que, ainda que se considere que as cooperativas não são sociedades, o critério ou critérios de determinação do beneficiário efetivo deve(m) ser construídos tendo como ponto de partida o que se encontra definido no art. $30^{\circ}$ da Lei $83 / 2017$ para as sociedades. Tanto as sociedades como as cooperativas são pessoas coletivas de base pessoal; em ambas os membros participam (ou podem participar, no caso dos membros investidores) no capital social; em ambas os membros podem ser pessoas coletivas; às cooperativas aplica-se como direito subsidiário o direito das sociedades e, em particular, o direito das sociedades anónimas. Estas razões justificam que se construa, por conseguinte, o critério de determinação do beneficiário efetivo, a partir das regras vigentes para o direito das sociedades. Não esquecendo, contudo, as especificidades próprias da identidade cooperativa.

\subsection{Criação e organização do registo interno de beneficiário efetivo}

Na transposição do Capítulo III da Diretiva (UE) 2015/849, o legislador português optou por um modelo em que as informações sobre o beneficiário efetivo constam de dois registos: o registo interno do beneficiário efetivo (arts. $4^{\circ}$ e $5^{\circ}$ da Lei 89/2017) e o registo central do beneficiário efetivo (previsto e regulado pelo Regime Jurídico do Registo Central de Beneficiário Efetivo (RJRCBE)).

O primeiro é de natureza e gestão privadas e segundo é de natureza e gestão públicas $^{24}$. O registo central de beneficiário efetivo é gerido pelo Instituto dos Registos e do Notariado, IP. (art. $2^{\circ}$ do RRCBE), que disponibiliza em página eletrónica (art. $19^{\circ}$ do RJRCBE) parte do vastíssimo acervo de informação constante desta base de dados. Tem, por conseguinte, natureza pública, quer quanto à entidade gestora quer quando ao acesso à informação.

\footnotetext{
${ }^{23}$ V. Coutinho de Abreu, J. M., «Artigo $2^{\circ} »$, Código cooperativo anotado, coord. de Deolinda Aparício Meira/Maria Elisabete Ramos, Almedina, Coimbra, 2018 (no prelo), ponto 3.; Ramos, Maria Elisabete, Direito comercial e das sociedades. Entre as empresas e o mercado, Almedina, Coimbra, 2018, p. 157 , ss.

${ }^{24}$ Este modelo dual de registos também é seguido pelo Reino Unido. «Since 6 April 2016 most companies, LLPs, and SEs have been required to hold a register of people with significant control and file the information on their register with Companies House. From 26 June 2017, unregistered companies and some listed companies will also be subject to these requirements. Also from 26 June 2017, eligible Scottish partnerships will be required to file information on their people with significant control (PSCs) with Companies House» - Guidance for registered and unregistered companies, societates europaeae, limited liability partnerships, and eligible Scottish partnerships (Scottish limited partnerships and Scottish qualifying partnerships), Department for Business, energy and Industrial Strategy, June 2017, pág.1, disponível em www.gov.uk/government/publications.
} 
Em ambos os registos são inscritas informações sobre os seus membros, com discriminação das respetivas participações sociais. Em ambos, a informação deve ser suficiente, exata, atual (arts. $4^{\circ}, 2$, da Lei 89/2017, e art. $1^{\circ}$ do RJRCBE). O que se compreende porque, várias entidades, designadamente, as instituições financeiras, dependem de tal informação para a tomada de decisões (arts. $29^{\circ}$ e ss. da Lei 83/2017).

No que às cooperativas diz respeito, o registo interno do beneficiário efetivo, previsto no art. $4^{\circ}$ da Lei $89 / 2017^{25}$, é criado e gerido por cada cooperativa, tem natureza privada (quer quanto à entidade gestora quer quanto ao acesso à informação) e está ao serviço, essencialmente, das obrigações declarativas da cooperativa.

Será dever do órgão de administração e de representação da cooperativa que, no âmbito dos deveres de cuidado ${ }^{26}$, prepare a estrutura organizatória de modo a que seja «instalado» e mantido atualizado o registo do beneficiário efetivo e assegure que acervo de informações cumpre integralmente as funções para que foi criado. No âmbito dos deveres de cuidado (art. 46 $\left.{ }^{\circ}, 1, b\right)$, do CCoop. ), em particular do dever de «controlo ou vigilância organizativo-funcional» ${ }^{27}$, compete aos administradores da cooperativa instalar e vigiar o funcionamento desta base de dados e a eles compete que ela seja devidamente atualizada e cumpra as exigências postas pela lei ${ }^{28}$.

A Lei 89/2017 é parca em pormenores sobre este registo interno do beneficiário efetivo e sobre o que se deve entender por «elementos de identificação» (art. $4^{\circ}, 1$ ). $\mathrm{O}$ art. $4^{\circ}$ da Lei 89/2017 impõe que «as sociedades devem manter um registo atualizado dos elementos de identificação», que abrange: $a$ ) os sócios, com a discriminação das respetivas participações sociais; $b$ ) as pessoas singulares que detêm, ainda que de forma indireta ou através de terceiro, a propriedade das participações sociais; $c$ ) quem, por qualquer forma, detenha o respetivo controlo.

Esta norma, diretamente dirigida às sociedades comerciais, é aplicável «com as necessárias adaptações» às cooperativas (art. $7^{\circ}$ da Lei 89/2017, e art. $3^{\circ}$, 1, a), do RRCBE). Uma das primeiras questões a resolver, de modo a concretizar as «ne-

\footnotetext{
${ }^{25}$ Esta disposição é aplicável às cooperativas por força da remissão combinada dos arts. $7^{\circ}$ da Lei 89/2017 e art. $3^{\circ}, 1, a$ ), do RRCBE.

${ }^{26}$ Sobre os deveres de cuidado dos administradores da cooperativa, v. Costa, Ricardo, «Artigo $46^{\circ} »$, Código Cooperativo anotado, coord. de Deolinda Meira e Maria Elisabete Ramos, Almedina, Coimbra, 2018 (no prelo).

${ }^{27}$ Coutinho de Abreu, J. M., «Deveres de cuidado e de lealdade dos administradores e interesse social», Reformas do Código das Sociedades, Almedina, Coimbra, 2007, pág. 20.

${ }^{28}$ Sobre o dever de legalidade dos administradores, v. Carneiro da Frada, M., «O dever de legalidade: um novo (e não escrito?) dever fundamental dos administradores», $D S R, 8$ (2012), pág.65, ss.; Ramos, Maria Elisabete, «Práticas restritivas da concorrência e deveres dos administradores de sociedades», DSR, ano 6, vol. 11 (2014), pág.107, ss.
} 
cessárias adaptações», é a de averiguar que sujeitos devem estar identificados no registo interno do beneficiário efetivo. Parece-me que, tendo em conta o teor dos arts. $19^{\circ}$ e $10^{\circ}$ do CCoop. , o registo interno deve recolher os elementos de identificação dos cooperadores (sejam eles fundadores ou não) e, caso existam, dos membros investidores. Ainda que sujeitos a estatutos jurídicos distintos, ambos são membros da cooperativa e, por tal razão, compõem a respetiva base subjetiva. Acresce que, relativamente a cooperadores e a membros investidores, justificam-se as mesmas exigências de identificação que se encontram consagradas para os sócios no art. $4^{\circ}$ da Lei 89/2017. Tanto cooperadores como membros investidores detêm interesses económicos relativamente à cooperativa - para os cooperadores, considere-se, a título de exemplo, a participação na atividade económica da

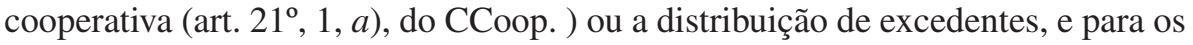
membros investidores considere-se a retribuição financeira do seu investimento, seja ele feito a título de subscrição de títulos de capital ou de subscrição de títulos de investimento (art. $20^{\circ}, 2$, do CCoop. ).

Tanto cooperadores como membros investidores podem não ser pessoas singulares e tanto uns como outros podem ser controlados por pessoas singulares que, essas sim, são os beneficiários efetivos dos interesses económicos detidos na cooperativa. Assim, parece-me que, relativamente às cooperativas, o registo interno do beneficiário efetivo deve integrar, de modo suficiente, exato e atual, os elementos de identificação de cooperadores, com a discriminação das respetivas participações no capital da cooperativa e, quanto aos membros investidores, a sua identificação e dos interesses económicos detidos ${ }^{29}$ (seja a participação em capital social, através de subscrição de títulos de capital, seja a subscrição de títulos de investimento).

A Lei 89/2017 é omissa sobre a forma como se organiza este registo interno que as cooperativas estão obrigadas a criar e a manter permanentemente atualizado. É certo que os comerciantes, conforme o art. $30^{\circ}$ do Código Comercial, na redação dada pelo DL 76-A/2006, beneficiam da liberdade de organização mercantil $^{30}$. Todavia, parece-me, que um dos aspetos que os titulares do órgão de administração e de representação devem atender na organização do registo interno do beneficiário efetivo é a lista de informações que a cooperativa, no cumprimento do seu dever de declarar ao registo central do beneficiário efetivo (arts. $3^{\circ}, 1$, a), $5^{\circ}$ do RJRCBE), deve incorporar na «declaração do beneficiário efetivo», tal como se encontram discriminadas nos art. $8^{\circ}$ e $9^{\circ}$ do RJRCBE.

\footnotetext{
${ }^{29}$ V. o art. $30^{\circ}$, 1, da (UE) Diretiva 2015/849 do Parlamento Europeu e do Conselho de 20 de maio de 2015 .

${ }^{30}$ Sobre esta liberdade de organização mercantil, v. J. M. Coutinho de Abreu, Curso de direito comercial, vol. I. Introdução, Atos de Comércio, Comerciantes, Empresas, Sinais Distintivos, $10^{\mathrm{a}}$ ed., Coimbra: Almedina, 2016, pág.189, com apreciação crítica da reforma introduzida pelo DL 76-A/2006, de 29 de março.
} 
Que cooperativas estão abrangidas? Eu diria que todas as cooperativas, sejam elas primeiro grau ou de grau superior, seja qual for o ramo em que se integrem e seja qual for a dimensão. Trata-se de uma exigência legal que envolverá a necessidade de adequar organizacionalmente a cooperativa e implicará os inerentes custos de incumprimento.

\subsection{Novas obrigações declarativas a cargo de membros da cooperativa}

Quem "alimenta" este registo cooperativo e interno do beneficiário efetivo? Em primeiro lugar, a cooperativa quando nele inscreve os elementos de identificação relativas: $a$ ) aos cooperadores e, eventualmente, membros investidores fundadores e respetivas participações na cooperativa e $b$ ) ao beneficiário efetivo, tal como resultam do ato constituinte da cooperativa. Parece ser o que resulta do art. $3^{\circ}$ da Lei 89/2017, adaptado às cooperativas por força dos arts. $7^{\circ}$ da Lei 89/2017 e do art. $3^{\circ}, 1, a$ ), do RRCBE. Parece, pois, que o art. $3^{\circ}$ da Lei 89/2017 consagra um novo dever legal a cargo de membros fundadores - o de, no ato constituinte da cooperativa, identificarem a pessoa singular-beneficiário efetivo das participações na cooperativa.

As informações prestadas pelos membros fundadores da cooperativa sobre quem é o beneficiário efetivo das participações devem ser verdadeiras, exatas $e$ atuais. Por força do art. $9^{\circ}$ do CCoop. , os membros da cooperativa estão sujeitos a responsabilidade civil prevista no art. $71^{\circ}$ do CSC, relativa à "responsabilidade quanto à constituição da sociedade" ${ }^{\prime 132}$. Efetivamente, o n. ${ }^{\circ} 1$ prevê a responsabilidade civil pela "inexatidão e deficiência das indicações e declarações prestadas com vista à constituição da sociedade", apresentando, por comparação ao regime geral da responsabilidade civil, certas particularidades em matéria de culpa e de ilicitude $e^{33}$. Na verdade, as indicações e declarações referidas no art. $71^{\circ}, 1$, parecem dizer respeito a informações prestadas com vista à constituição da sociedade. Justamente, o art. $3^{\circ}$ da Lei 89/2017 consagra uma manifestação de tal dever de exatidão - do dever de o membro da cooperativa identificar, para efeitos ato constituinte, com exatidão e completude a identificação da pessoa singular que é

\footnotetext{
${ }^{31}$ Coutinho de Abreu, J. M./ Ramos, Maria Elisabete, «Artigo $7^{\circ} »$, Código das Sociedades Comerciais em comentário, coord. de J. M. Coutinho de Abreu, vol. I, $2^{a}$ ed., Almedina, Coimbra, 2017, pág.882, ss. V. tb. Aires de Sousa, Susana, «Responsabilidade criminal por informações falsas ou incompletas sobre a vida da sociedade comercial», E depois do Código das Sociedades Comerciais em Comentário, IDET, Colóquios, nº 6 (2016), Almedina, Coimbra, pág. 67, ss.; Aires de Sousa, Susana, «Direito Penal das Sociedades Comerciais. Qual o Bem Jurídico?», Revista Portuguesa de Ciência Criminal, Ano 12 (2002), n. ${ }^{\circ}$, janeiro-março, Coimbra Editora, Coimbra, pág.49, ss..

${ }^{32}$ Nos termos do art. $38^{\circ}$ do RRCBE, «quem prestar falsas declarações para efeitos do registo do beneficiário efetivo, para além da responsabilidade criminal em que incorre, nos termos do art. $348^{\circ}$-A do Código Penal, responde civilmente pelos danos a que der causa».

${ }^{33}$ Coutinho de Abreu, J. M./ Ramos, Maria Elisabete, «Artigo $71^{\circ} »$, cit., pág. 889.
} 
o beneficiário efetivo. Informação que a cooperativa irá inscrever no seu registo privado de beneficiário efetivo.

\section{RESPONSABILIDADE CIVIL POR DECLARAÇÕES INEXATAS OU DEFICIENTES}

$\mathrm{O}$ art. $71^{\circ}, 1$, do CSC comina com responsabilidade civil solidária a prestação de informações inexatas ou deficientes. Trata-se de uma responsabilidade dos membros fundadores perante a cooperativa assente na violação de disposições legais que consagram deveres dos fundadores perante a sociedade. E embora tais normas possam garantir também interesses de outros sujeitos (sócios e credores), parece não haver razões que afastem a natureza obrigacional da responsabilidade dos fundadores perante a cooperativa ${ }^{34}$. Da natureza obrigacional da responsabilidade resulta que se presume a culpa dos fundadores (art. $799^{\circ}, 1$, do CCiv.). Esta presunção de culpa beneficia a cooperativa, porque, invertendo o ónus da prova da culpa (art. $350^{\circ}, 1$, do CCiv.), dispensa-a de provar este requisito de responsabilidade civil ${ }^{35}$. Para os efeitos do art. $71^{\circ}, 1$, os fundadores são responsáveis perante a sociedade a título de dolo ou de negligência.

Efetivamente, a insuficiência ou a inexatidão das informações prestadas pelos membros fundadores sobre a pessoa singular beneficiário efetivo pode ser causalmente adequado a provocar danos no património da cooperativa - danos provocados pelas coimas ou outras sanções aplicadas em razão do incumprimento das obrigações a cargo da cooperativa (v. arts. $6^{\circ}$ da Lei 89/2017 e $37^{\circ}$ da Lei 89/2017, esta última norma relativa ao incumprimento das obrigações declarativas por parte da cooperativa $\left.{ }^{36}\right)$.

\section{Do CUMPRIMENTO DA OBRIGAÇÃO DE ATUALIZAÇÃO PERMANENTE DO REGISTO INTERNO DE BENEFICIÁRIO EFETIVO}

Tendo a cooperativa promovido a primeira inscrição no registo interno, socorrendo-se das informações colhidas no ato constituinte (art. $3^{\circ}$ da Lei 89/2017), é obrigação de todo o membro da cooperativa informar a cooperativa de qualquer alteração aos elementos de identificação previstos no art. $4^{\circ}$ (art. $5^{\circ}, 1$, da Lei 89/2017). Esta obrigação legal de informação deve ser cumprida no (curto) prazo de 15 dias a contar da alteração.

Em face dos arts. $4^{\circ}$ e $5^{\circ}$ da Lei $89 / 2017$, importa questionar se a cooperativa pode atualizar/completar o registo do beneficiário efetivo socorrendo-se de

\footnotetext{
${ }^{34}$ Coutinho de Abreu, J. M./ Ramos, Maria Elisabete, «Artigo 71», cit., pág. 888

${ }^{35}$ Coutinho de Abreu, J. M./ Ramos, Maria Elisabete, «Artigo $71^{\circ} »$, cit., pág. 889.

${ }^{36} \mathrm{~V}$. infra.
} 
outras fontes de informação, que não sejam os seus membros. Por um lado, a Lei 89/2017 não afasta esta possibilidade de a cooperativa se socorrer de outras fontes de informação. Por outro lado, a cooperativa é a entidade gestora do registo do beneficiário efetivo e a ela compete assegurar que a informação nele reunida seja suficiente, exata e atual. Além disso, enquanto declarante, a cooperativa deve comunicar (nomeadamente ao registo central) informações suficientes, exatas e atuais sobre o beneficiário efetivo (arts. $1^{\circ}, 3^{\circ}$ do RRCBE). Acresce que o incumprimento do dever de atualizar o registo de beneficiário efetivo e do dever de declarar implica a aplicação de coimas (art. $6^{\circ}$ da Lei 89/2017) e as sanções previstas no art. $37^{\circ}$ do RJRCBE.

Não sendo um registo de acesso público, para que serve este registo privado-cooperativo de beneficiário efetivo? Essencialmente, este registo do beneficiário efetivo reúne a informação necessária ao cumprimento das obrigações declarativas a cargo da cooperativa. Retira-se esta conclusão dos arts. $4^{\circ}, 2,7^{\circ}$ da Lei 89/2017, e do art. $3^{\circ}, 1$, a), do RRCBE. Por um lado, esta informação será comunicada pela sociedade às «entidades obrigadas» quando a solicitem no âmbito do cumprimento do seu dever de diligência quanto à clientela (art. $33^{\circ}$ da Lei 83/2017). Por outro lado, este registo permite à sociedade cumprir o seu dever de declarar, previsto no art. $5^{\circ}$ do $\mathrm{RJRCBE}^{37}$.

\section{DO REGISTO CENTRAL DO BENEFICIÁRIO EFETIVO - PUBLICIDADE E RESTRIÇÃO DE DIREITOS FUNDAMENTAIS}

Nem ao membro fundador nem ao beneficiário efetivo são impostas obrigações declarativas para com o registo central do beneficiário efetivo. Incumbe à cooperativa o dever legal de apresentar, junto do registo central, a declaração de beneficiário efetivo (arts. $5^{\circ}, 8^{\circ}$ do RJRCBE) ${ }^{38}$. Na declaração do beneficiário efetivo são recolhidos os dados elencados no art. $9^{\circ}$ do RJCCBE.

Nos termos do art. $18^{\circ}$ do RJCBE, «a declaração do beneficiário efetivo é refletida no RCBE por transmissão eletrónica de dados, de acordo com a informação prestada no formulário, a que ser refere o $\mathrm{n}^{\circ} 1$ do artigo $11^{\circ}$, desde que tenha sido prestada por pessoa com legitimidade».

São de acesso público e gratuito o nome, o mês e o ano do nascimento, a nacionalidade, o país da residência e o interesse económico detido pelo beneficiário efetivo (arts. $19^{\circ}, 39^{\circ}, 2$, do RJRCBE).

\footnotetext{
${ }^{37}$ Recorde-se que a Diretiva (UE) 2015/849, no art. 30, 1, impõe que os "Estados-Membros asseguram que [as entidades societárias] são obrigadas a apresentar às entidades obrigadas, além das informações sobre o proprietário legal, informações sobre o beneficiário efetivo, quando as entidades obrigadas tomarem medidas de diligência quanto à clientela nos termos do Capítulo II". As interpolações não constam do texto original.

${ }^{38}$ Sobre o cumprimento da obrigação declarativa, v. o art $11^{\circ}$ do RRCBE.
} 
Este nível de acesso público, através de Internet, desvinculado da invocação de interesse público não é exigido pela Diretiva. Na verdade, o art. $30^{\circ}, 5$, da Diretiva determina que «Os Estados-Membros asseguram que as informações sobre os beneficiários efetivos estão acessíveis em todos os casos: a) Às autoridades competentes e às UIF, sem restrições; $b$ ) Às entidades obrigadas, no quadro da diligência quanto à clientela nos termos do Capítulo II; $c$ ) A quaisquer pessoas ou organizações que possam provar um interesse legítimo. As pessoas ou organizações a que se refere a alínea $c$ ) têm acesso pelo menos ao nome, mês e ano de nascimento, à nacionalidade e ao país de residência do beneficiário efetivo, bem como à natureza e extensão do interesse económico detido.».

Ora, é importante referi-lo, o art. $30^{\circ}, 5$ da Diretiva 2015/849 determina que «quaisquer pessoas ou organizações que possam provar um interesse legítimo» têm acesso pelo menos "ao nome, mês e ano de nascimento, à nacionalidade e ao país de residência do beneficiário efetivo, bem como à natureza e extensão do interesse económico detido". No processo de transposição para a ordem jurídica interna, o legislador franqueou o acesso público a estes dados pessoais, dispensando o acesso da prova do interesse legítimo, antecipando a solução que, mais tarde, veio a ser consagrada pela Diretiva EU 2018/843 do Parlamento Europeu e do Conselho de 30 de maio de 2018.

A Comissão Nacional de Proteção de Dados, em parecer que teve por objeto a proposta de lei preparatória do Regime Jurídico do Registo Central do Beneficiário Efetivo ${ }^{39}$, apreciou muito criticamente este «nível de acesso público» ${ }^{40}$, constante atualmente do art. $19^{\circ}$ do RJRCB. Eis as objeções formuladas pela Comissão Nacional de Proteção de Dados: a) a publicação na internet do nome, mês, ano de nascimento, nacionalidade, país de residência e interesse económico detido é desnecessária para a prevenção do branqueamento de capitais e do financiamento do terrorismo; $b$ ) as autoridades encarregadas de combater o branqueamento de capitais e o financiamento do terrorismo já têm acesso a essa informação; $c$ ) essa publicitação através da internet implica a "perpetuação da informação, bem como a sua reprodução e o cruzamento infinitos" que não são travados pelo cancelamento do registo do beneficiário efetivo.

Segundo a Comissão Nacional de Proteção de Dados, a exposição na internet das referidas informações pessoais restringe excessivamente os direitos fundamentais ao respeito pela vida privada e pela proteção dos dados pessoais, consa-

${ }^{39}$ Trata-se do Parecer n. ${ }^{\circ}$ 29/2017, relativo ao Processo n..$^{\circ}$ 6841/2017.

${ }^{40}$ Comissão Nacional de Proteção de Dados, Parecer 29/2017, pág.5 v. Segundo este Parecer, o legislador justifica este «nível de acesso público» em duas vertentes: «promove uma maior transparência e, simultaneamente, assegura a cabal execução das obrigações fixadas na Diretiva (UE) n. ${ }^{\circ}$ 2015/849, do Parlamento Europeu e do Conselho, de 20 de maio de 2015, no que tange à garantia de acesso de qualquer interessado a um conjunto fundamental de dado, sem a necessidade de densificação do conceito de «interesse legítimo»». 
grados no arts. $26^{\circ}$, 1 , e $35^{\circ}$ da CRP e arts. $7^{\circ}$ e $8^{\circ}$ da Carta dos Direitos Fundamentais da União Europeia.

$\mathrm{O}$ art. $22^{\circ}$ do Regime do Registo do Beneficiário Efetivo prevê restrições especiais de acesso, em caso de risco de fraude, rapto, extorsão, violência ou intimidação, ou quando o beneficiário efetivo for incapaz ou menor.

\section{DO INCUMPRIMENTO INJUSTIFICADO DA OBRIGAÇÃO DE INFORMAÇÃO A CARGO DO MEMBRO DA COOPERATIVA - ALGUMAS QUESTÕES JURÍDICAS}

Determina o art. $5^{\circ}$, n. $^{\circ} 3$, da Lei n. ${ }^{\circ}$ 89/2017 que o «incumprimento injustificado do dever de informação pelo sócio, após a notificação prevista no número anterior, permite a amortização das respetivas participações sociais, nos termos previstos no Código das Sociedades Comerciais, aprovado pelo Decreto-Lei n. ${ }^{\circ}$ 262/86, de 2 de setembro, designadamente nos seus artigos $232^{\circ}$ e $347^{\circ}$ ».

O incumprimento injustificado do dever de informação a cargo do sócio permite que a sociedade amortize a participação social, com a consequente extinção desta. Extinguindo-se a participação social cessa também a «propriedade indireta» de tais participações sociais e cessa a extração, por essa via, de benefícios económicos. Este parece ter sido o propósito desta inovação legislativa. Perante a opacidade sobre quem é o beneficiário efetivo, resultante da não atualização, da insuficiência e inexatidão da informação, corta-se o mal pela raiz, extinguindo a participação social ${ }^{41}$.

Quando aplicado o art. $5^{\circ}$, n. ${ }^{\circ} 3$, da Lei n. ${ }^{\circ}$ 89/2017 às cooperativas, a questão que se põe é a de saber qual é sanção aplicada ao membro da cooperativa que incumpre a obrigação de informação. Sabendo que o Código Cooperativo não prevê a figura da amortização de participação social, qual é a sanção aplicável, depois de introduzidas as «necessárias adaptações»? Parece que a questão é a de saber qual é a sanção que, o regime jurídico-cooperativo, tem efeitos equiparáveis à amortização de quotas ou de ações. O que não é uma questão simples porque, desde logo, o CSC não apresenta um regime unitário de amortização de participações sociais. Assim, com diferentes regimes jurídicos, é regulada, por um lado, a amortização de quota e, por outro a amortização de ações. E, neste último caso, o CSC distingue entre a amortização sem redução do capital social (art. $346^{\circ}$ do CSC) e a amortização com redução do capital social (art. $347^{\circ}$ do CSC).

Parece, no entanto, que o art. $5^{\circ}, 3$, da Lei n. ${ }^{\circ}$ 89/2017 pretende que, perante o incumprimento injustificado do sócio, a sociedade delibere amortizar a quota do sócio incumpridor (e, por consequente, extinguir a participação social) ou

\footnotetext{
${ }^{41}$ Sobre este tema, Ramos, Maria Elisabete, «Controlo de identidade dos sócios - alguns problemas recentes», V Congresso Direito das Sociedades em Revista, Almedina, Coimbra, 2018 (no prelo).
} 
delibere amortizar as ações e, consequentemente, extinguir a participação social e, neste caso, reduzir o capital social (art. $347^{\circ}, 5$, do CSC). Ou seja, parece que a Lei 89/2017 pretende que, perante o incumprimento injustificado do sócio e a opacidade sobre quem é o beneficiário efetivo, a sociedade reaja extinguindo a participação social.

Parece, pois, que as «necessárias adaptações» (art. $7^{\circ}$ da Lei 89/2017), requeridas para permitir a aplicação do art. $5^{\circ}$, 3, da Lei 89/2017 às cooperativas hão-de respeitar o resultado que a lei pretende que seja obtido - ou seja, extinguir-se a qualidade de membro da cooperativa. Mas para que a cooperativa sancione o incumprimento injustificado com a perda de qualidade de membro, terá de atuar no contexto dos quadros jurídico-cooperativos em vigor, uma vez que a Lei 89/2017 não alterou o Código Cooperativo.

$\mathrm{O}$ «regime disciplinar» aplicável a cooperadores está previsto no art. $25^{\circ}$ do CCoop. e contempla, enquanto sanção mais grave, a exclusão (art. 25ㅇ, 1,e), do CCoop. ), sendo que compete à assembleia geral a aplicação da referida sanção (art. $25^{\circ}, 6$, do CCoop. ). Tendo em conta o teor literal do art. $25^{\circ}$ do CCoop. , ele não se aplica a membros investidores, mas tão-só a cooperadores. O que suscita a questão de saber se a sanção de exclusão é ou não aplicável também a membros investidores ${ }^{42}$.

Acontece, ainda, que a exclusão de membro (cooperador ou membro investidor) exige a «violação grave e culposa» enquanto o art. $5^{\circ}$ da Lei 89/2017 exige tão-só um incumprimento injustificado. Quid iuris, se o incumprimento injustificado da obrigação de informação não configurar, em concreto, uma violação grave e culposa? Será, ainda, lícito excluir o membro da cooperativa ou tal deliberação da cooperativa será inválida? Este é um dos muitos problemas que a aplicação do art. 5, 3 , da Lei 89/2017 suscita.

\section{SANÇÕES APLICÁVEIS À COOPERATIVA}

O incumprimento do membro da cooperativa da sua "obrigação de informação" não é causa justificativa de incumprimento das suas obrigações declarativas perante o registo central do beneficiário efetivo. Este parece ter sido o objetivo da lei, quando permite que o incumprimento injustificado do membro da cooperativa determine a extinção da qualidade de membro, deliberada pela própria cooperativa.

A que sanções se expõe a cooperativa que não cumpre as suas obrigações declarativas?

${ }^{42}$ Almeida Martins, André, «Artigo $25^{\circ} »$, Código Cooperativo anotado, coord. de Deolinda Meira/ Maria Elisabete Ramos, Almedina, Coimbra, 2018, nt. 6 (no prelo), pronuncia-se no sentido de que o art. $25^{\circ}$ também se aplica aos membros investidores. 
O incumprimento do dever de manter o registo societário do beneficiário efetivo constitui contraordenação punível com coima de 1000 euros a 50000 euros (art. $6^{\circ}, 1$, da Lei 89/2017). Aplica-se o regime dos ilícitos contraordenacionais contemplado na Lei 83/2017 (art. $6^{\circ}$, 2, da Lei 89/2017). A entidade competente para aplicar esta coima é, nos termos do art. $121^{\circ}, 3$, do CCoop. competem à Cooperativa António Sérgio para a Economia Social.

A cooperativa incumpridora de obrigações declarativas perante o RCBE expõe-se a sanções mais graves e severas que se encontram previstas no art. $37^{\circ}$ do RRCBE. O que indicia que a lei dá muito mais relevo ao incumprimento da obrigação declarativa perante o registo central do beneficiário efetivo do que ao registo societário de beneficiário efetivo. O que se compreende, tendo em conta a função jurídico-social deste último

Por fim, o art. $38^{\circ}$ do RRCBE, com o objetivo de assegurar a veracidade das informações prestadas "para efeitos do registo do beneficiário efetivo", determina que quem prestar falsas declarações, para além da responsabilidade criminal em que incorre, nos termos do art. $348^{\circ}$-A do Código Penal, responde civilmente pelos danos a que der causa".

\section{A Diretiva (UE) 2018/843 do Parlamento Europeu e do Conselho, de 30 DE MAIO DE 2018}

Em 19 de junho de 2018 foi publicada no Jornal Oficial da União Europeia a Diretiva UE 2018/843 do Parlamento Europeu e do Conselho, de 30 de maio de 2018, que introduz importantes modificações à Diretiva 2015/849. Estas alterações são justificadas pela necessidade de a União Europeia se adaptar às novas ameaças, designadamente no que se refere à forma como os "grupos terroristas financiam e conduzem as suas operações" (considerando 2).

Há, pois, nas palavras da Diretiva de 2018 que criar um ambiente "hostil" aos criminosos (considerando 4), designadamente pelo reforço de transparência "das estruturas societárias" e de outras pessoas coletivas (considerandos 2, 3). Quer-se, desta forma, evitar que os criminosos dissimulem a sua identidade em estrutura societária. Ressalva esta Diretiva de 2018 que a luta contra o terrorismo e o financiamento do terrorismo deve respeitar o direito fundamental à proteção dos dados pessoais, bem como a observância e a aplicação do princípio da proporcionalidade (c. 5).

Como criar um clima hostil aos criminosos? A Diretiva responde que tal desiderato é conseguido pelo acesso do público (designadamente imprensa) a informações sobre os beneficiários efetivos e estruturas de controlo das sociedades, especialmente em sistemas de governo das sociedades que se caraterizam por uma concentração da propriedade (considerando 30). 
Ouçamos a Diretiva de 2018: "Os Estados-Membros deverão, pois, permitir o acesso a informações sobre os beneficiários efetivos das entidades societárias (...) de uma forma suficientemente coerente e coordenada, através dos registos centrais $(\ldots)$ estabelecendo uma regra clara de acesso público, de modo que terceiros possam verificar, em todo o território da União, quem são os beneficiários efetivos". O que vai ser conseguido através da interconexão dos registos centrais dos Estados-Membros que possuem informações sobre os beneficiários efetivos, através da Plataforma Central Europeia.

Em consequência, é alterado, designadamente, o art. $30^{\circ}$ da Diretiva 2015/849 (sobre beneficiários efetivos de entidades societárias). Eis as principais alterações: a) clarifica-se que são os beneficiários efetivos quem fornece às entidades societárias todas as informações necessárias, designadamente sobre o interesse económico detido; $b$ ) o "interesse legítimo" deixa de ser critério de acesso do público às informações sobre os beneficiários efetivos de entidades societárias (art. $30^{\circ}, 5$, c)); c) os "membros do público" podem ter acesso a, pelo menos, ao nome, mês e ano de nascimento, país de residência e de nacionalidade do beneficiário efetivo, bem como à extensão do interesse económico detido; d) permite que os Estados-Membros franqueiem o acesso público a informações adicionais, como a data de nascimento e os dados de contacto, em conformidade com as normas relativas à proteção dos dados.

Eu diria que alguns destes resultados já estão consagrados na legislação portuguesa. Se não vejamos: $a$ ) o art. $19^{\circ}$ do RRCBE prescinde do "critério público" para franquear o acesso público a dados pessoais de beneficiários efetivos; $b$ ) o art. $19^{\circ}, 1, b$ ), do RCBE permite o acesso público a "nome, o mês e ano de nascimento, a nacionalidade, o país de residência e o interesse económico detido" pelo beneficiário efetivo.

É questionável em que medida a publicitação do mês, ano ou data de nascimento é necessária e absolutamente imprescindível para prevenir a utilização do sistema financeiro para efeitos de branqueamento de capitais ou de financiamento de terrorismo.

A Diretiva UE 2018/843 do Parlamento Europeu e do Conselho, de 30 de maio de 2018 tem de ser transposta até 10 de janeiro de 2020.

\section{Questões Relativas À ENTRADA EM VIGOR DA Lei 89/2017}

A Lei n. ${ }^{\circ}$ 89/2017, de 21 de agosto, fixou um período de vacatio legis de 90 dias, contados após a data da publicação (art. $25^{\circ}$ ). Ressalva-se, no entanto, o disposto na norma transitória do art. $22^{\circ}$ da Lei 89/2017 relativa à «primeira declaração inicial relativa ao beneficiário efetivo». Ora, esta deve ser cumprida no «prazo definido por portaria dos membros do Governo responsáveis pelas áreas das finanças e da justiça». 
Por outro lado, o art. $23^{\circ}$ da Lei 89/2017 determina que a «regulamentação prevista no Regime Jurídico do RCBE (...) é publicada no prazo de 90 dias, a contar do dia seguinte ao da publicação da presente lei». Embora prometida a publicação no prazo de 90 dias, «a contar do dia seguinte ao da publicação» da lei, a verdade é que tal regulamentação ainda não foi publicada.

Um dos aspetos do regime que necessita de regulamentação da Portaria é a definição do formulário eletrónico através do qual a cooperativa (e outras entidades) irá cumprir a sua obrigação declarativa perante o Registo Central do Beneficiário Efetivo (art. $11^{\circ}, 1$, do RRCBE).

Entretanto a Comissão Nacional de Proteção de Dados, no Parecer n. ${ }^{\circ}$ 23/2018, também se pronunciou sobre o projeto de portaria e manifestou várias reservas. Em síntese, a CNPD recomenda: $a$ ) o formulário dever refletir as circunstâncias indiciadoras de beneficiário efetivo elencadas no arts. $30^{\circ}$ a 34 da Lei 83/2017; $b$ ) as pesquisas no RCentral do Beneficiário efetivo devem ser feitas através do número civil e não do número fiscal; $c$ ) deve ser regulado o acesso às informações por parte das entidades competentes, de modo a restringi-lo aos casos em que há motivo; $d$ ) o projeto deve indicar quem, no interior das organizações públicas, pode ter acesso aos dados constantes do Registo do Beneficiário Efetivo.

A Comissão Nacional de Proteção de dados pessoais reafirma as fragilidades constitucionais da norma que permite a divulgação pública de dados pessoais dos beneficiários efetivos.

\section{Conclusão}

A Lei 89/2017, de 21 de agosto, transpõe para a ordem jurídica interna o Capítulo III da Diretiva EU 2015/849, dedicado às «Informações sobre o beneficiário efetivo». Impondo aos Estados-Membros que as informações sobre o proprietário legal e sobre o beneficiário efetivo sejam conservadas em registo central em cada Estado-Membro, simultaneamente a Diretiva exige que os Estados-Membros asseguram que as entidades societárias são obrigadas a apresentar às «entidades obrigadas» informações sobre o «proprietário legal» e sobre o «beneficiário efetivo».

O Estado Português cumpriu estas obrigações internacionais relativas às «informações sobre o beneficiário efetivo», criando dois registos do beneficiário efetivo: o registo interno, gerido pela cooperativa e de natureza privada e o registo central do beneficiário efetivo, de acesso público (ainda que com diferentes níveis de acesso), e gerido pelo Instituto dos Registos e do Notariado, IP.

As modificações legislativas introduzidas pela Lei 89/2017 deixaram intocadas as normas em vigor sobre os registos do ato constituinte da cooperativa e sobre as regras relativas ao cumprimento de obrigação de entrada ou de outras contribuições que não integram o capital social. No entanto, a Diretiva UE 2015/849 
é clara em afirmar que a «realização de pagamentos de elevados montantes em numerário é altamente vulnerável ao branqueamento de capitais e ao financiamento do terrorismo» (Considerando (6)).

No que tange o estatuto de membro da cooperativa, a Lei 89/2017 introduziu novas obrigações declarativas para com a cooperativa.

$\mathrm{Na}$ verdade, a Lei 89/2017 exige que no ato constituinte seja identificado o beneficiário efetivo da participação social (art. $3^{\circ}$ da Lei 89/2017). Salvo melhor opinião, parece que esta norma impõe que cada membro da cooperativa identifique, para efeitos do ato constituinte, a pessoa singular que é o beneficiário efetivo. O que configura, parece, uma declaração/informação do membro da cooperativa com vista à constituição da sociedade. Esta obrigação de declaração do membro da cooperativa, perante esta, está sujeita aos requisitos do art. $71^{\circ}$ do CSC, por força do art. $9^{\circ}$ do CCoop, relativo à responsabilidade quanto à constituição da sociedade. Por força desta disposição, as declarações inexatas ou incorretas causadoras de danos à sociedade são sancionadas com a responsabilidade civil contratual do membro da cooperativa.

Para além dessa obrigação declarativa, o membro da cooperativa encontra-se obrigado a informar a cooperativa de toda a alteração aos elementos de identificação constantes do . $^{\circ} 1$ do art. $4^{\circ}$ da Lei 89/2017. Ou seja, o membro da cooperativa deve informar a cooperativa de alterações relativas aos seus elementos de identificação e da sua participação social, como lhe compete comunicar à sociedade as alterações aos elementos de identificação do beneficiário efetivo. Esta obrigação declarativa deve ser cumprida no prazo de 15 dias a contar da data da alteração.

O registo do beneficiário efetivo parece estar ao serviço das obrigações declarativas da própria cooperativa seja relativamente ao registo central do beneficiário efetivo, seja para satisfazer as solicitações das chamadas «entidades obrigadas» a deveres de diligência quanto à sua clientela. $\mathrm{O}$ membro da cooperativa não tem obrigações declarativas relativamente ao registo central do beneficiário efetivo.

A enciclopédica base de dados do registo central do beneficiário efetivo apresenta vários níveis de acesso às suas informações. Alguns das informações sobre o beneficiário efetivo são de acesso público através da Internet, nos termos do art. $19^{\circ}$ da RJRCBE, dispensando o legislador português que tal acesso esteja submetido ao crivo do «interesse legítimo». A Comissão Nacional de Proteção de Dados analisa de forma muito crítica este acesso público através da internet e considera tal solução legislativa inconstitucional, porque desnecessária para proteção da integridade do sistema financeiro.

Também é suscetível de suscitar dúvidas quanto à adequação constitucional a extinção potestativa da qualidade de membro da cooperativa, como reação ao incumprimento injustificado da obrigação de informação do sócio. É questionável se a extinção da participação social constitui a medida justa para reagir a qualquer 
incumprimento injustificado a obrigação de informar por parte do membro da cooperativa.

\section{BIBLIOGRAFIA E OUTRAS FONTES}

ABREU, J. M. Coutinho de , «Deveres de cuidado e de lealdade dos administradores e interesse social», Reformas do Código das Sociedades, Almedina, Coimbra, 2007.

ABREU, J. M. Coutinho de, Curso de direito comercial, vol. I. Introdução, Atos de Comércio, Comerciantes, Empresas, Sinais Distintivos, 10ª ed., Coimbra: Almedina, 2016.

ABREU, J. M. Coutinho de / Ramos, Maria Elisabete, «Artigo 71», Código das Sociedades Comerciais em comentário, coord. de J. M. Coutinho de Abreu, vol. I, $2^{\mathrm{a}}$ ed., Almedina, Coimbra, 2017.

ABREU, J. M. Coutinho DE «ARTigo $2^{\circ} »$, Código cooperativo anotado, coord. de Deolinda Meira/Maria Elisabete Ramos, Almedina, Coimbra, 2018 (no prelo).

ABREU, Miguel Cancela de, «Private benefits of controlo - Do aproveitamento pessoal do controlo societário», DSR, 8, 15 (2015).

ALARCÓN FIDALGO, Joaquín, «La aportación del uso masivo de datos (big data) y de la cadena de bloques (blockchain) a la cadena de valor del seguro», RES, 173 (2018)

ANTUNES, José Engrácia, «A titularidade por conta de participações sociais - breve apontamento», DSR, 10, 19 (2018).

CORREIA, F. Mendes, «A tecnologia descentralizada de registo de dados (Blockchain)», $O$ novo Direito dos Valores Mobiliários. I Congresso sobre Valores Mobiliários e Mercados Financeiros, coord. de Paulo Câmara, Almedina, Coimbra, 2017.

COSTA, J. de FARIA, «Responsabilidade jurídico-penal da empresa e dos seus órgãos (ou a reflexão sobre a alteridade nas pessoas colectivas à luz do direito penal)», in: Direito penal económico e europeu: textos doutrinários, vol., I. Problemas gerais, Coimbra Editora, Coimbra, 1998.

COSTA, Ricardo, «Artigo $141^{\circ} »$, Código das Sociedades Comerciais em comentário, coord. de J. M. Coutinho de Abreu, vol. II, $2^{\text {a }}$ ed., Almedina, Coimbra, 2015.

COSTA, Ricardo, «Artigo $142^{\circ} »$, Código das Sociedades Comerciais em comentário, coord. de J. M. Coutinho de Abreu, vol. II, 2a ed., Almedina, Coimbra, 2015.

CUNHA, C., «Artigo $112^{\circ} »$, Código Coopeativo anotado, coord. de Deolinda Meira, Maria Elisabete Ramos, Almedina, Coimbra, 2018 (no prelo).

CUNHA, C., «Artigo $113^{\circ}$ », Código Coopeativo anotado, coord. de Deolinda Meira, Maria Elisabete Ramos, Almedina, Coimbra, 2018 (no prelo).

FIRTH-BUTTERFIELD, Kay; BRENT, Richard; GRANT, Tom, Part. VIII Future of the International Law of Tainted Money, 24 Virtual Currencies, Artificial Intelligence, and Emerging Legal Questions, Banks and Financial Crime: The international law of tainted Money, $2^{\text {nd }}$ edition, Oxford Legal Research Library, 2017.

FRADA, M. Carneiro da, «O dever de legalidade: um novo (e não escrito?) dever fundamental dos administradores», DSR, 8 (2012).

Guidance for registered and unregistered companies, societates europaeae, limited liability partnerships, and eligible Scottish partnerships (Scottish limited partnerships and Scottish 
qualifying partnerships), Department for Business, energy and Industrial Strategy, June 2017, disponível em www.gov.uk/government/publications.

MARTINS, André Almeida, «Artigo 25», Código Cooperativo anotado, coord. de Deolinda Meira/Maria Elisabete Ramos, Almedina, Coimbra, 2018 (no prelo).

MEIRA, Deolinda, «Artigo $114^{\circ} »$, Código Coopeativo anotado, coord. de Deolinda Meira, Maria Elisabete Ramos, Almedina, Coimbra, 2018 (no prelo).

OECD, Behind the corporate veil. Using corporate entities for illicit purposes, 2001

PAECH, Philipp, «The governance of blockchain financial networks», Modern Law Review, 80, 6 (2017).

Parecer do Banco Central Europeu, Opinion of the European Central Bank of 12 October 2016 on a proposal for a directive of the European Parliament and of the Council amending Directive (EU) 2015/849 on the prevention of the use of the financial system for the purposes of money laundering or terrorist financing and amending Directive 2009/101/EC (CON/2016/49)

RAMOS, Maria Elisabete, $O$ seguro de responsabilidade civil dos administradores. Entre a exposição ao risco e a delimitação da cobertura, Almedina, Coimbra, 2010.

RAMOS, Maria Elisabete, «Práticas restritivas da concorrência e deveres dos administradores de sociedades», DSR, 6, vol. 11 (2014).

RAMOS, Maria Elisabete, Direito comercial e das sociedades. Entre as empresas e o mercado, Almedina, Coimbra, 2018.

RAMOS, Maria Elisabete, «Controlo de identidade dos sócios - alguns problemas recentes», $V$ Congresso Direito das Sociedades em Revista, Almedina, Coimbra, 2018 (no prelo).

SOUSA, S. Aires de, «A responsabilidade criminal do dirigente: algumas considerações acerca da autoria e comparticipação no contexto empresarial», Estudos em Homenagem ao Prof. Doutor Jorge de Figueiredo Dias, Boletim da Faculdade de Direito, Stvdia Ivridica 98, Vol. II, 2009/2010.

SOUSA, Susana Aires DE, «Direito Penal das Sociedades Comerciais. Qual o Bem Jurídico?», Revista Portuguesa de Ciência Criminal, Ano 12 (2002), n. ${ }^{\circ}$ 1, janeiro-março, Coimbra Editora, Coimbra.

SOUSA, S. Aires de, «Societas publicas (non) delinquere potest: reflexões sobre a irresponsabilidade dos entes públicos no ordenamento jurídico português», Actas do XV Encuentro AECA Nuevos caminos para Europa: El papel de las empresas y los gobiernos, 20-21 de setembro de 2012, Obra digital, disponível em <http://www.aeca.es/ xvencuentroaeca/cd/7f.pdf>.

SOUSA, Susana Aires de, «Responsabilidade criminal por informações falsas ou incompletas sobre a vida da sociedade comercial», E depois do Código das Sociedades Comerciais em Comentário, IDET, Colóquios, nº 6, Almedina, Coimbra, 2016.

WALKER, George; Purves, Robert; Blair, Michael, Finantial Services Law, $4^{\text {th }}$ edition, 2018. 